\title{
KEARIFAN LOKAL MASYARAKAT DALAM MELESTARIKAN BATANG AIE LUNANG DI KENAGARIAN LUNANG KECAMATAN LUNANG KABUPATEN PESISIR SELATAN
}

\author{
Deni Fatma Sari \\ Program Studi Pendidikan Geografi STKIP PGRI Sumatera Barat \\ fatmadenisari@gmail.com
}

\begin{abstract}
This research aim to get information or data and analyse exhaustively about local wisdom of society in preserve bar of aie Lunang in Kenagarian Lunang District Of Lunang Sub-Province Coastal area of South. Result of research show 1) Knowledge of society about is important of him continuity of bar region of aie to life seen from willingness for bertanggungjawab about continuity of bar of aie in the form of prohibition order catching fish with fish poison and also do not impinge assumed order oppose against norm and value around bar of aie and also the existence of dubious to all breaking of the rule 2) Understanding of society about local wisdom in taking care of bar region of aie very is needed, because bar of aie represent one of the very natural resources many its function to life 3) Habit of regional society of bar of aie pertained goodness and still hold gentleman's agreement firmness and norm going into effect seen from habit of society which do not use fish poison to catch fish, [do] not throw away garbage around bar of aie, using clothes which appropriately when bath in bar of aie and 4) Confidence of society that bar of aie the necessary for life of them and if impinging norm and order going into effect they believe the existence of dubious and debacle to which impinge it.
\end{abstract}

Keyword: local wisdom, Society

Abstrak
Penelitian ini bertujuan untuk mendapatkan data atau informasi dan menganalisis secara mendalam tentang kearifan lokal masyarakat dalam melestarikan batang aie Lunang di Kenagarian Lunang Kecamatan Lunang Kabupaten Pesisir Selatan. Hasil penelitian menunjukkan: 1) Pengetahuan masyarakat tentang pentingnya kelestarian wilayah batang aie bagi kehidupan terlihat dari kemauan untuk bertanggungjawab tentang kelestarian batang aie dalam bentuk larangan menangkap ikan dengan racun ikan serta tidak melanggar aturan yang dianggap bertentangan dengan nilai dan norma disekitar batang aie serta adanya sangsi bagi para pelanggar peraturan tersebut, 2) Pemahaman masyarakat tentang kearifan lokal dalam menjaga wilayah batang aie sangat diperlukan, karena batang aie merupakan salah satu sumber daya alam yang sangat banyak fungsinya bagi kehidupan 3) Kebiasaan masyarakat wilayah batang aie tergolong baik dan masih memegang teguh adat kesopanan dan norma yang berlaku terlihat dari kebiasaan masyarakat yang tidak menggunakan racun ikan untuk menangkap ikan, tidak membuang sampah di sekitar batang aie, menggunakan pakaian yang sewajarnya ketika mandi di batang aie dan 4) Keyakinan masyarakat bahwa batang aie penting bagi kehidupan mereka dan apabila melanggar aturan dan norma yang berlaku mereka meyakini adanya sangsi dan petaka bagi yang melanggarnya.

Kata Kunci: Kearifan Lokal, masyarakat

\section{PENDAHULUAN}

Indonesia merupakan negara yang memiliki cadangan air terkaya didunia. Ketersediaan air mencapai $15.500 \mathrm{~m} 3$ per kapita per tahun (Prihatin, 2013) yang di kutip oleh Nugroho (2014). Prihatin menambahkan, meskipun demikian tidak terdapat jaminan kemudahan akses bagi masyarakat untuk memperoleh air bersih. 
Air merupakan komponen yang sangat penting dalam kehidupan makhluk hidup di alam ini. Selain itu, air juga merupakan barang milik umum sehingga air dapat mengalami persoalan besar dan merupakan barang milik bersama berada dalam kondisi buruk karena tidak adanya kepemilikan, sehingga hampir semua orang menjadi 'penumpang gratis' yang merasa memiliki dan boleh menggunakan sumberdaya tersebut, akibatnya semua orang menjadi penyebab rusaknya sumberdaya tersebut.

Pada dasawarsa ini, keberadaan air bersih menjadi langka. Kendati dua pertiga planet kita terdiri atas air, kelangkaan air terus terjadi (Shiva, 2002) yang dikutip oleh Nugroho (2014). Shiva menjelaskan bahwa kelangkaan menyebabkan kesehatan dan pembangunan ekonomi suatu negara akan terhambat. Pemanfaatan kekayaan alam indonesia sesuai dengan UUD 1945 pasal 37 ayat 3 yang berbunyi bumi dan air merupakan kekayaan alam yang terkandung didalamnya dikuasai oleh negara dan digunakan untuk sebesar-besarnya bagi kemakmuran rakyat termasuk didalamnya kekayaan perairan dan kekayaan lainnya.

Sumberdaya air bukan hanya saja dimanfaatkan untuk kehidupan tetapi pengelolaannya sangat penting sekali dilakukan agar tidak terjadinya krisis sumberdaya air dimasa yang akan datang. Pengelolaan sumberdaya air yang tepat sangat penting untuk mengakomodasi krisisnya sumberdaya air, mewujudkan konservasi air, dan pendayagunaan sumberdaya air yang berkelanjutan (Kodoeatie, 2008) yang dikutip oleh Nugroho (2014). Agar tujuan pengelolaan sumberdaya air terwujud, maka diperlukan peran serta dan kontribusi dari semua pemangku kepentingan (stakeholder) yang terdiri dari pemerintah, swasta, dan masyarakat.

Menurut Asdak (2006), yang dikutip oleh Nugroho (2014), mengatakan bahwa masyarakat menjadi salah satu pemegang kunci keberhasilan pelestarian air. Lebih lanjut dikatakan olehnya bahwa krisis air bersumber pada sistem produksi, distribusi, dan konsumsi. Maka upaya pelestarian air dapat dilakukan melalui pengelolaan sumberdaya air yang mampu diimplementasikan dalam kehidupan sehari-hari. Dalam hal ini karakteristik sosial budaya masyarakat, 
termasuk peran sertanya dalam menjaga ketersediaan sumberdaya air merupakan faktor penting yang tidak dapat dipisahkan dari suatu ekosistem.

Kondisi tanah air Indonesia yang menghasilkan alam dengan keanekaragaman ekosistem beserta sumberdaya alam, melahirkan manusia indonesia yang akrab dengan alam seperti pola pertanian (waktu tanam, waktu menuai, dan memungut hasil), menangkap ikan kelaut dan lainnya. Manusia Indonesia menanggapi alam sebagai guru pemberi petunjuk gaya hidup masyarakat, yang terlahir dalam bentuk kebiasaan alami yang dituangkan menjadi adat kehidupan yang beriontasi pada sikap alam takambang menjadi guru (Salim, 2006) yang dikutip oleh Pawarti (2012).

Kearifan tradisional atau kearifan lokal merupakan salah satu warisan budaya yang ada di masyarakat (tradisional) dan secara turun-temurun dilaksanakan oleh masyarakat yang bersangkutan. Kearifan tradisional tersebut umumnya berisi ajaran untuk memelihara dan memanfaatkan sumberdaya alam (hutan, tanah, dan air) secara berkelanjutan. Dari sisi lingkungan hidup keberadaan kearifan tradisional sangat menguntungkan karena secara langsung ataupun tidak langsung sangat membantu dalam memelihara lingkungan serta mencegah terjadinya kerusakan lingkungan (Lampe, 2006) yang dikutip oleh Pawarti (2012).

Kekayaan sungai merupakan kearifan lokal masyarakat sekitar sungai dan didalamnya terkandung pula kearifan budaya lokal. Kearifan budaya local sendiri adalah pengetahuan lokal yang sudah sedemikian rupa menyatu dengan sistem kepercayaan, norma, dan budaya serta diekspresikan dalam tradisi dan mitos yang dianut dalam jangka waktu yang lama (Aminudin, 2013).

Kearifan lokal adalah pengetahuan, pemahaman, dan kebiasaan yang mengarahkan kehidupan manusia dalam kehidupan masyarakat dalam komunitas ekologis. Kehidupan lokal berguna baik sebagai pengetahuan hidup maupun sebagai perilaku manusia dalam melestarikan lingkungan (Hamidy, 2001) yang dikutip oleh Amri (2013). Saam (2011), yang dikutip oleh Amri (2013), juga menyebutkan bahwa kearifan lokal itu berkembang dalam kehidupan sehari-hari melalui ajaran langsung dari orang tua kepada anaknya maupun dari ninik mamak 
kepada cucu kemenakannya. Adapun cara lain dalam penyampaian kearifan tersebut seperti melalui petatah-petitih, pantang larang dan sastra lainnya.

Kearifan lokal sebenarnya merupakan modal sosial dalam perspektif pembangunan berkelanjutan yang berwawasan lingkungan kiranya penting untuk digali, dikaji, dan ditempatkan pada posisi strategis untuk dikembangkan menuju pengelolaan sumber daya alam dan lingkungan kearah yang lebih baik (Siswadi, 2010), yang dikutip oleh Renjaan (2013). Nayati (2006), yang dikutip oleh Renjaan (2013). berpendapat bahwa masalah kearifan lingkungan erat kaitannya dengan ilmu bagaimana orang arif terhadap ciptaan tuhan dan dirinya sendiri untuk kelangsungan hidup yang berkelanjutan.

Tindakan arif bukan hanya pada dirinya saat ini berfikir bagaimana berperilaku arif untuk kelangsungan generasi yang akan datang yang sejalan dengan prinsip pembangunan berkelanjutan. Dalam Undang-Undang Nomor 32 Tahun 2009 tentang Perlindungan dan Pengelolaan Lingkungan Hidup menetapkan kewajiban pemerintah untuk menetapkan sustainable development sebagai solusi untuk memperbaiki kerusakan lingkungan tanpa mengorbankan kebutuhan pembangunan ekonomi dan keadilan sosial. Penerapan prinsip pembangunan berkelanjutan dalam pembangunan nasional memerlukan kesepakatan semua pihak untuk memadukan pilar pembangunan secara proporsional. Konsep pembangunan berkelanjutan timbul dan berkembang karena timbulnya kesadaran bahwa pembangunan ekonomi dan sosial tidak dapat dilepaskan dari kondisi lingkungan hidup (Renjaan, 2013). Menurut Gobyah (2003), yang dikutip oleh Diandri (2014), kearifan lokal (local genius) adalah kebenaran yang telah mentradisi atau ajeg dalam suatu daerah.

Kearifan lokal merupakan perpaduan antara nilai-nilai suci firman tuhan dan berbagai nilai yang ada. Kearifan lokal terbentuk sebagai keunggulan budaya masyarakat setempat maupun kondisi geografis, dalam arti luas kearifan lokal merupakan produk budaya masa lalu yang terjadi secara terus menerus dan dijadikan pedoman hidup. Meskipun bernilai lokal tetapi nilai yang terkandung didalamnya di anggap sangat universal. Adapun menurut Keraf (2010), menyatakan bahwa kearifan lokal adalah semua bentuk pengetahuan, keyakinan, 
pemahaman atau wawasan serta adat kebiasaan atau etika yang menuntun perilaku manusia dalam kehidupan di dalam komunitas ekologis. Jadi kearifan lokal ini bukan hanya menyangkut pengetahuan dan pemahaman masyarakat adat tentang manusia dan bagaimana relasi yang baik di antara manusia, melainkan juga menyangkut pengetahuan, pemahaman dan adat kebiasaan tentang manusia, alam dan bagaimana relasi di antara semua penghuni komunitas ekologis ini harus dibangun.

Seluruh kearifan tradisional ini dihayati, dipraktikkan, diajarkan dan diwariskan dari satu generasi ke generasi lain yang sekaligus membentuk pola perilaku manusia sehari-hari, baik terhadap sesama manusia maupun terhadap alam dan yang gaib (http://ewintribengkulu.blogspot.com/2012/11/konsepkearifan-lokal html).

Lingkungan hidup merupakan bagian yang mutlak dari kehidupan. Salah satu komponen lingkungan adalah sumberdaya alam hayati berupa flora dan fauna sebagai modal dasar pembangunan nasional dan mempunyai peranan penting bagi kelangsungan kehidupan dipermukaan bumi. Kekayaan sumberdaya alam itu harus dipelihara dan dimanfaatkan secara optimal untuk kesejahteraan dan mutu manusia. Pengelolaan dan pemanfaatannya mesti dilakukan secara serasi, selaras, dan seimbang. Upaya ini disebut juga konservasi sumberdaya alam (pelestarian sumberdaya alam) (Diandri, 2014).

Pengaruh sistem budaya lokal telah melahirkan cara berfikir dan bertindak yang memandang hubungan manusia dan alam fisik adalah hubungan internal yang bersifat persuasif, sehingga keberlanjutan sumberdaya alam hayati perairan dapat terjaga. Kearifan lokal yang sering dikonsepsikan sebagai pengetahuan setempat (local knowledge), kecerdasan setempat (local genius), dan kebijakan setempat (local wisdom), oleh UU RI No. 32 Tahun 2009 tentang perlindungan dan pengelolaan lingkungan hidup dimaknai sebagai nilai-nilai luhur yang berlaku dalam tata kehidupan masyarakat yang antara lain dipakai untuk melindungi dan mengelola lingkungan hidup secara lestari, di Kenagarian Lunang Kecamatan Lunang Kabupaten Pesisir Selatan telah diterapkan dalam pengelolan Batang Aie atau sungai. Batang Aie Lunang yang terletak di Kenagarian Lunang dengan 
wilayah hutan Sako sebagai daerah hulu Batang Aie, melewati kampung medan jaya, kampung rantau ketaka, dan kampung lubuk sitepung sebagai daerah tengah Batang Aie, serta bagian hilir yang merupakan area perkebunan masyarakat dan wilayah hutan.

Berdasarkan observasi awal peneliti pada tanggal 20 Juni 2015, peneliti melihat bahwa kelestarian batang aie Lunang masih terjaga dengan baik. Salah satu bentuk bahwa batang aie Lunang masih terjaga kelestariannya adalah terlihat dari kondisi airnya yang masih jernih, tidak adanya wilayah batang aie yang dijadikan sebagai area penambangan, masih baiknya vegetasi yang tumbuh disekitar batang aie serta tidak terlihatnya sampah-sampah yang dapat mengotori batang aie.

Kondisi batang aie Lunang yang masih baik tidak terlepas dari pengaruh budaya lokal yang telah berlangsung secara turun temurun di Lunang. Kearifan lokal masyarakat Lunang dalam menjaga batang aie Lunang terlihat dalam prilaku masyarakat yang tidak menangkap ikan dengan racun ikan, tidak membuang sampah disekitar batang aie, serta tidak berlaku kurang baik, mandi telanjang, berkata kotor dan takabur ketika beraktivitas disekitar batang aie karena masyarakat sangat meyakini bahwa batang aie adalah sesuatu yang sakral, apabila masyarakat melanggar maka akan ada sanksi dan petaka yang didapatkan.

Sanksi yang ada berupa denda uang dan makanan yang kemudian diberikan kemesjid bagi masyarakat yang menangkap ikan dengan racun ikan dan membuang sampah. Adapun petaka yang pernah terjadi di batang aie Lunang adalah peristiwa dimakan buaya penunggu batang aie Lunang yang terjadi pada beberapa masyarakat yang berlaku tidak baik, mandi telanjang dan berbicara kotor.

\section{METODOLOGI}

Jenis penelitian ini adalah penelitian kualitatif. Penelitian ini dilakukan di Kenagarian Lunang Kecamatan Lunang Kabupaten Pesisi Selatan. Informan penelitian ini diambil secara purposive sampling. Informan dalam penelitian ini adalah masyarakat di sekitar Batang Aie Lunang sedangkan informan kunci dalam penelitian ini adalah Mandeh Rubiah sebagai masyarakat adat serta Wali Nagari 
sebagai aparat pemerintah. Data dianalisis dengan metode yang dikemukakan oleh Miles dan Huberman dikutip oleh Sugiyono (2013), dengan langkah-langkah sebagai berikut : (1) reduksi data, (2) penyajian data, dan (3) penarikan kesimpulan.

\section{PEMBAHASAN}

Berdasarkan hasil temuan dilapangan dan sesuai dengan tujuan penelitian maka didapatkan hasil tentang kearifan lokal masyarakat dalam melestarikan batang aie Lunang di Kenagarian Lunang Kecamatan Lunang sebagai sebagai berikut:

Masyarakat memiliki pengetahuan terhadap batang aie Lunang yang sudah ada dari zaman dahulu sampai sekarang. Adanya pengetahuan masyarakat menuntun masyarakat untuk bagaimana berprilaku positif dan bentuk tanggung jawab yang diberikan disekitar batang aie Lunang sehingga dengan adanya pengetahuan yang didukung budaya local kelestarian batang aie dapat terjaga. Bentuk prilaku positif masyarakat dalam melestarikan batang aie Lunang adalah masyarakat tidak menggunakan racun ikan dalam menangkap ikan, tidak membuang sampah disekitar batang aie, tidak berkata kotor dan takabur disekitar wilayah batang aie, menggunakan pakaian yang sewajarnya ketika mandi.

Pengetahuan masyarakat tentang adanya sangsi dan petaka bagi yang melanggar aturan yang dianggap bertentangan dengan nilai dan norma disekitar batang aie Lunang. Sangsi tersebut berupa uang, makanan ataupun teguran oleh pemangku adat dan pemerintahan nagari Lunang.

Hal ini sesuai dengan pendapat (Wietoler, 2007) dalam Diandri (2014), bahwa masyarakat dengan pengetahuan yang telah ada di dalam kehidupan masyarakat semenjak zaman dahulu mulai dari zaman pra-sejarah sampai sekarang ini, kearifan tersebut merupakan perilaku positif manusia dalam berhubungan dengan alam dan lingkungan sekitarnya yang dapat bersumber dari nilai-nilai agama, adat istiadat, petuah nenek moyang atau budaya setempat.

Pemahaman masyarakat tentang kearifan lokal dalam menjaga wilayah batang aie sangat diperlukan, karena batang aie merupakan salah satu sumber daya alam yang sangat banyak fungsinya bagi kehidupan. Bentuk pemahaman 
tersebut diantaranya: 1) paham bahwa wilayah batang aie harus dijaga kelestariannya dan 2) paham menjaga batang aie dengan cara tidak mengotori wilayah batang aie merupakan syarat untuk kelestarian lingkungan. Masyarakat di sekitar batang aie Lunang umumnya masih sangat bergantung pada batang aie oleh karena itu batang aie penting untuk dijaga kelestariannya agar manfaat batang aie tidak mudah hilang. Adanya kearifan lokal dipahami sebagai bentuk menjaga kelestarian batang aie dari kerusakan.

Hal ini sesuai dengan pendapat Sardiman (2003) pemahaman adalah menguasai sesuatu dengan pikiran.Konsep adalah ide (abstrak) yang dapat digunakan atau memungkinkan seseorang untuk mengelompokkan atau menggolongkan sesuatu objek.

Kebiasaan masyarakat wilayah batang aie tergolong baik dan masih memegang teguh adat kesopanan dan norma yang berlaku. Bentuk kebiasaan tersebut diantaranya: 1) tidak menggunakan racun ikan dalam menangkap ikan, 2) tidak membuang sampah di sekitar batang aie, 3) tidak berkata kotor dan takabur di sekitar wilayah batang aie, 4) menggunakan pakain yang sewajarnya ketika mandi di batang aie (tidak telanjang badan/memakai pakaian dalam) saja baik untuk laki-laki maupun perempuan.

Kebiasaan masyarakat juga tergambar dari kemauan untuk mematuhi peraturan tentang larangan menggunakan racun ikan untuk menangkap ikan. Hal ini sesuai dengan pendapat Tampubolon (2003) menyebutkan bahwa "kebiasaan adalah perilaku, yaitu suatu sikap atau kegiatan yang bersifat fisik atau mental, yang telah mendarah daging atau membudaya dalam diri seseorang.

Masyarakat yakin bahwa batang aie penting bagi kehidupan mereka apabila melanggar aturan dan norma yang berlaku mereka meyakini adanya sanksi dan petaka bagi yang melanggarnya. Masyarakat meyakini adanya suatu kekuatan gaib seperti terjadi kecelakaan ataupun kehilangan nyawa apabila sesuatu yang dianggap menyimpang dari norma yang berlaku yang dilakukan di sekitar lingkungan batang aie. Bentuk keyakinan tersebut diantaranya: 1) menjaga lingkungan batang aie penting karena manfaat dan fungsi batang aie banyak sekali bagi kehidupan 2) adanya sanksi dan petaka bagi yang melanggar aturan yang 
tidak sesuai dengan norma karena wilayah batang aie merupakan tempat yang sakral.

Hal ini sesuai dengan pendapat Keraf (2002) dalam Diandri (2014), adalah semua bentuk pengetahuan, keyakinan, pemahaman atau wawasan serta adat kebiasaan atau etika yang menuntun perilaku manusia dalam kehidupan di dalam komunitas ekologis. Dijelaskan pula bahwa kearifan

Lokal/tradisional bukan hanya menyangkut pengetahuan dan pemahaman masyarakat tentang manusia dan bagaimana relasi yang baik di antara manusia, melainkan juga menyangkut pengetahuan, pemahaman dan adat kebiasaan tentang manusia, alam dan bagaimana relasi di antara penghuni komunitas ekologis ini harus dibangun.

\section{KESIMPULAN}

1. Pengetahuan masyarakat dalam melestarikan batang aie Lunang adalah masyarakat mengetahui tentang adanya sangsi dan petaka bagi yang melanggar aturan yang dianggap bertentangan dengan nilai dan norma disekitar batang aie Lunang. Sangsi tersebut berupa denda dengan sejumlah uang, makanan ataupun teguran oleh pemangku adat nagari Lunang. Adanya pengetahuan lokal membuat masyarakat disekitar batang aie Lunang mau bertanggung jawab tentang kelestarian batang aie Lunang tersebut

2. Bentuk kearifan lokal dilihat dari pemahaman masyarakat dalam melestarikan batang aie Lunang adalah masyarakat memahami bahwa wilayah batang aie harus dijaga kelestariannya, masyarakat paham menjaga batang aie dengan cara tidak mengotori wilayah batang aie merupakan syarat untuk kelestarian lingkungan.

3. Bentuk kearifan lokal dilihat dari kebiasaan masyarakat dalam melestarikan batang aie Lunang adalah kebiasaan masyarakat yang tidak menggunakan racun ikan dalam menangkap ikan, tidak membuang sampah di sekitar batang aie, tidak berkata kotor dan takabur di sekitar wilayah batang aie, menggunakan pakain yang sewajarnya ketika mandi di batang aie (tidak telanjang badan/memakai pakaian dalam) saja baik untuk laki-laki maupun perempuan. 
4. Bentuk kearifan lokal dilihat dari keyakinan masyarakat dalam melestarikan batang aie Lunang adalah keyakinan masyarakat bahwa menjaga lingkungan batang aie penting karena manfaat dan fungsi batang aie banyak sekali bagi kehidupan dan adanya sanksi dan petaka bagi yang melanggar aturan yang tidak sesuai dengan norma karena wilayah batang aie merupakan tempat yang sakral.

\section{DAFTAR PUSTAKA}

Aminudin, 2013. Menjaga Lingkungan Hidup Dengan Kearifan Lokal. Titian Ilmu.Bandung

Amri. 2013. Kearifan Lokal Lubuk Larangan Sebagai Upaya Pelestarian Sumberdaya Perairan Didesa Pangkalan Indarung Kabupaten Kuantan Singingi.

Jurnal. Ilmu Lingkungan Program Pascasarjana Universitas Riau Aulia. 2010. Kearifan Lokal Dalam Pengelolaan Sumber Daya Air Di Kampung Kuta.

Jurnal. Departemen Sains Komunikasi Dan Pengembangan Masyarakat, Fakultas Ekologi Manusia, IPB

Baharudin, 2012. Kearifan lokal, pengetahuan lokal dan degradasi lingkungan. Jurnal. Fakultas Ilmu Komunikasi,Universitas Esa Unggul, Jakarta

Diandri, Novi. 2014. Kearifan Lokal Masyarakat Nelayan Dalam Menjaga Lingkungan Wilayah Pesisir Di Kenagarian Surantih Kecamatan Sutera. Skripsi. Program Studi Pendidikan Geografi. Sekolah Tinggi Keguruan Dan Ilmu Pendidikan Sumatera Barat

(http://digilib.uinsbg.ac.id/872/5/Bab2.pdf) diakses tanggal 25 Agustus 2015. (http://digilib.unila.ac.id./7451/16/BabII.pdf) diakses tanggal 25 Agustus 2015.

Moleong, 2010. Metodologi Penelitian kualitatif Edisi Revisi. Remaja Rosda Karya, Bandung

Nugroho, 2014. Kearifan Masyarakat Using Didesa Kemiren Kecamatan Glagah Kabupaten Banyuwangi Provinsi Jawa Timur Dalam Konservasi Air. Skripsi. Fakultas Kehutanan, Universitas Gadjah Mada Yogyakarta Nuraeni, 2012. Studi Budaya Di Indonesia. Pustaka Setia. Bandung〉 
Pawarti, 2012. Nilai PelestarianLingkungan Dalam Kearifan Lokal Lubuk Larangan Ngalau Agung Dikampung Surau Kabupaten Dharmasraya Provinsi Sumatera Barat. Prosiding Seminar Nasional Pengelolaan Sumberdaya Alam Dan Lingkungan

Renjaan, 2013. Studi Kearifan Lokal Sasi Kelapa Pada Masyarakat Adat Kei Desa Ngilngof Kecamatan Kei Kecil Kabupaten Maluku Utara.Tesis. Program Magister Ilmu Lingkungan, Program Pascasarjana Universitas Diponegoro Semarang.

Riduwan, 2010. Belajar Mudah Penelitian Untuk Guru-Karyawan Dan Peneliti Pemula. Alfabeta. Bandung

Sartini. 2004. Menggali Kearifan Lokal Nusantara Sebuah Kajian Filsafat. Jurnal Filsafat: Agustus 2004, Jilid 37, Nomor 32.yogyakarta

Siswadi, 2010.Kearifan Lokal Dalam Melestarikan Air (Studi Kasus Di Desa Purwogonda, Kecamatan Boja, Kabupaten Kendal)

Jurnal. Ilmu Lingkungan Volume 9, Issue 2 : 63-68 (2011)

Sugiyono, 2013. Metode Penelitian Kuantitatif Kualitatif Dan $R \&$ D. Alfabeta. Bandung.

Suhartini, 2009. Kajian Kearifan Lokal Masyarakat Dalam Pengelolaan Sumberdaya Alam Dan Lingkungan.Jurnal. Jurusan Pendidikan Biologi Fmipa Universitas Negeri Yogyakarta.

Syamsiyatun, 2013. Filsafat, Etika, Dan Kearifan Lokal. Globethics. Geneva 